\section{S.J. van der Merwe}

Prof. S.J. van der Merwe, Faculty of Theology, Northwest University, South Africa. E-mail: sarel.vandermerwe@nwutheology. co.za.

ORCID: https://orcid. org/0000-0002-86232632.

\section{O.G. Thebe}

Mr. O.G. Thebe, Faculty of Theology, Northwest University, South Africa. E-mail: ogthebe@gmail. com

ORCID: https://orcid. org/0000-0002-52998912.

DOI: http://dx.doi. org/10.18820/23099089/ actat.Sup28.7 ISSN 1015-8758 (Print) ISSN 2309-9089 (Online) Acta Theologica 2019

Suppl 28:104-120

Date Published:

6 December 2019

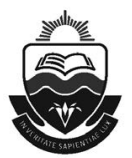

Published by the UFS http://journals.ufs.ac.za/index.php/at (c) Creative Commons With Attribution (CC-BY) OPEN ACCESS

\section{THE CONUNDRUM} FACING CHRISTIAN TRADITIONAL LEADERS

\section{ABSTRACT}

Although Christianity was introduced to and embraced by Batswana over two centuries ago, some Batswana still hold dear to their traditions, customs and cultures, which, at times, are not in line with the Word of God. Volz (2008:112) concedes that, although European missionaries introduced Batswana to Christianity, they had hardly any control over how early Batswana converts perceived and adapted their teachings. In some instances, dikgosi, ${ }^{1}$ as traditional leaders, are still facing a serious conundrum of being a Christian, on the one hand, and a custodian of culture, on the other. This is in line with the view expressed by Amanze (2003:43) that many Christians, especially members of the African Independent Churches, live a strange life, with one foot rooted in the African traditional beliefs and the other in Christian beliefs and practices. Given the statement "For there is only one God and one mediator between God and men, the man Christ Jesus" (1 Tim. 2:5), the question is: Where does this place traditions, customs and culture?

\section{INTRODUCTION}

This article is dedicated to Pieter Verster as a missiologist who emphasised Jesus Christ

1 Plural of a Setswana word "Kgosi", which means King/Chief. He is a traditional leader vested with wide powers, including the custodianship of the whole land, traditions and customs of his subjects. 
as our atonement (Verster 2017). He conducted an in-depth research in townships and rural villages and always asked the question as to what it means for our daily lives to believe in Jesus Christ. Verster is clear about the unique meaning of Jesus Christ. It is a privilege to know and work with him and to be able to make use of his extensive research. He always focuses on Jesus Christ who was crucified for our sins. His book Jesus Christus, Seun van God, is ons Versoening, 'n Missionêre Christologie (2017) is a new mission paradigm for our present era.

In a postcolonial period, it is also important to study the custodians of traditional culture and their understanding of Christianity. Do they transform culture from within, in order to give account of Christ's atonement and victory, or do they live in two worlds, afraid to question their own culture in light of Jesus Christ's work?

\section{TRADITIONAL LEADERS - CUSTODIANS OF CULTURE}

From time immemorial, dikgosi have not only been endowed with the responsibility of being rulers, but they were also viewed as mediators, judges and custodians of the traditions, customs and culture of their communities and/or subjects. According to Samatar (1997:688), in the precolonial era, the ultimate authority of any Batswana settlement was vested in a Kgosi. In matters of importance, a Kgosi, despite his unchallenged authority and power, would consult with his chiefs before making a major decision.

Since those ancient times, Batswana's belief system has governed their everyday life. They have always believed that life cannot simply be lived in a vacuum and that there needs to be a structural order. The foundations or cornerstones of that structural order were and still are their traditions, culture and customs, which have always been so entrenched in communities that they form the Batswana worldview. As such, they are passed on through stories, tales and myths and are, at times, enforced without question. Any drastic or significant change to traditions, culture or even customs thus has the potential to affect and change the Batswana world view. Conversely, a change in world view can also have a tremendous impact on culture. On the issue of world view, Van der Walt (2001:67) reminds us that, unlike the West that is concerned with the past, present and future, Africans emphasise the past.

It is, therefore, crucial to note that a Kgosi, as a traditional leader with ultimate authority over his people, carries the burden of preserving those customs and culture to ensure that they are passed on from generation 
to generation. Kgosi Lehatshe Mankuroane (2017) of Batlhaping ba-gaPhuduhucwana in Taung, North-West province, is of the view that these traditions and customs are crucial, for they are the glue that sustains social cohesion among the tribes and gives them their identity.

Kgosi Mankuroane's view is also held by Van der Walt (2008:477), who contends that, in a traditional African society, tradition should not be tampered with. It is a bond that holds the society in one grip and, for this reason, members of that particular society cannot risk straying from that fixed tradition. This is so, in that various myths and rituals sustain the existing order, in accordance to which they position themselves. Tradition is essential for an orderly society.

Similarly, Cant et al. (2006:56) propound that culture is not a narrow outlook on society's activities, but rather encompasses all those activities that embody the behaviour of a particular society - the way they talk, their appearance and their general social patterns. Walters (2010:38) views culture as a collective encoding or indoctrination of the mind, which then characterises and differentiates members of one category of society from those of another category. In agreement with Walters, Anagwo (2014:280) views culture as a complex total that comprises knowledge, belief, art, morals, law, customs and any other capabilities and habits acquired by man as a member of society.

In summing up the above views on culture, it makes sense to suggest that culture is an integrated and amalgamated system of beliefs about God, values and customs, and of institutions that give expression to those beliefs to the extent of them binding a community, society or nation together, thereby giving them a sense of common identity, security and dignity.

In conversation with Kgosi Mankuroane (2017), it also becomes clear that tribes or communities are loyal to their traditions and want to uphold them at all costs, for they go to the root of every tribe, its identity, and what it stands for. He insists that taking away traditions and customs would be equal to erasing the past or, even worse, taking away the soul and identity of a tribe. This would leave them without a culture and identity.

A conundrum arises when a Kgosi becomes a Christian and those very customs and cultures that he ought to preserve and pass on to other generations are in conflict with his newly acquired beliefs and faith. In such an instance, the question is: What does such a leader do? Does he forge ahead with his traditional responsibility of preserving and protecting the culture of his people, despite Christianity, or simply abdicate such responsibility? Or does he simply endeavour to distinguish and separate 
his personal belief from his role as a representative or custodian of the community values as a collective?

\section{CULTURAL PRACTICES VERSUS CHRISTIANITY}

One of the issues that exacerbate the conundrum facing traditional leaders is the view held by some that their culture is beyond reproach and, therefore, not subject to the transforming power of the gospel and the Holy Spirit. For example, Mbiti (1977:28) argues that

cultural imperialism must terminate first in order to allow the indigenous culture to relate more effectively to the gospel, on its own terms and without pressure from outside. With humility and gratitude let us borrow and learn from other cultures but let us not become their cultural slaves.

Mbiti's (1977) argument almost elevates culture over and above the gospel, in that he seems to suggest that the gospel can only be related to in ways dictated by culture. It could well be that Mbiti's stance is informed by the fact that the Holy Spirit had no place in the African traditional religion. According to Amanze (2000:3),

one of the most distinctive characteristics of African traditional religions in general and Tswana in particular is belief in a Supreme Being.

Amanze's views are completely in line with Ray (1976:50) who stated categorically that

[i]t is generally recognised that there are two fundamentally different types of divinities in African religion: the one creator god, who is usually remote from daily religious life, and the many gods and spirits which are constantly involved in everyday religious experience.

In other words, there was no role for both Jesus Christ and the Holy Spirit.

For his part, Hiebert (2006:377-378) reckons that difference in culture is the main problem in the missionary task of ministering the gospel to people of different nations. Putting salt in the wound of this situation is the stance embraced and communicated by Kgosi Mankuroane (2017), namely that culture gives the community its identity and that it is the glue that sustains social cohesion.

A major challenge always arises when cultural practices are perceived to be contrary to the Word of God or contradictory to Christian principles. For example, Volz (2008:128) records that tension arose among 
Barolong-boo-Ratshidi in 1862 when young Christian converts refused to participate in initiation rites. At first, Kgosi Montshiwa allowed the converts to forgo initiation, but as the Christians also refused to participate in various other communal rituals, he became increasingly concerned that the tribe would ultimately split and perish.

Nowadays, initiation is one of the cultural practices that Kgosi Mankuroane (2017) deems important to adhere to. He was insistent in his explanation that Bogwera and Bojale, ${ }^{2}$ as age-old cultural practices, cannot be changed, because his tribal authority and, by extension, the tribe maintain that it is through these customs that the youth of the tribe are taught the customs and culture of the tribe. Even more importantly, it is through the process of initiation that the youth learn their future roles as men and women to ensure an orderly society in which respect prevails.

On the subject of initiation, Kgosi spoke of how this practice or system relates particularly to the status of men in society. This is so in that mophato ${ }^{3}$ would always be led by a prince. Before leaving for initiation, they would gather in the royal kraal where the reigning Kgosi would give that mophato a name and his blessings. Every young man would then carry that name as a symbol or status in society, until his death. Naming mophato is a way of classifying age groups, but not necessarily their roles in society. In all likelihood, mophato would then be made up of young men or women of the same age group.

In the above scenario, the conundrum facing a Christian Kgosi is what he should do as a custodian of traditions and culture. Does the advice of Apostle Paul become applicable: "... do not be conformed to this world but be transformed ..." (Rom. 12:2)?

Beware lest anyone cheat you through philosophy and empty deceit, according to the tradition of men, according to the basic principles of the world and not according to Christ (Col. 2:8)?

The president of the erstwhile Bophuthatswanagovernment, the late Kgosi Lucas Manyane Mangope, stood against this cultural practice and upheld his Christian conviction. Besides his role as President of Bophuthatswana, the late Mangope was Kgosi of Bahurutshe-boo-Manyane at Motswedi near Zeerust. According to Shaffer (1963:6-7), the young Mangope, who was later to become a teacher, a politician and president, was led to salvation by Reverend Samuel Makhaola of the Assemblies of God. Kgosi Mangope had

2 Male and female circumcision.

3 An initiation regiment or battalion. 
serious misgivings about the circumcision school and the witchcraft that came with it and stood against it.

Another cultural practice that is deemed to be in conflict with Christianity is that of ancestor veneration. Jebadu (2007:250) explains that the word "ancestor" is derived from the Latin verb antecedere, which means to go before, or the Latin noun antecessor, which means somebody who goes before. To put it in simpler terms, Amanze (2003:43) mentions that the word "ancestor" is generally used to signify the dead predecessors of a family, clan or tribe.

\begin{abstract}
But for him who is joined to all the living there is hope, for a living dog is better than a dead lion. For the living know that they will die, but the dead know nothing, and they have no more reward for the memory of them is forgotten. Also, their love, their hatred and their envy have now perished. Nevermore will they have a share in anything done under the sun (Eccles. 9:4-6).
\end{abstract}

Notwithstanding, Nyirongo (1997:51) states that Africans (like the Batswana) developed the strong belief that God could not be approached directly, but only through intermediaries, and consequently worshipped through the ancestors. Africans held the view that God, as a supernatural being, was spiritual and could, therefore, only communicate with other spiritual or spirit beings. It is for this reason that Africans believed that only their deceased relatives, who were regarded as spirit beings, could communicate directly with God as a supernatural being. They, therefore, needed the ancestors to act on their behalf and to intercede for them with the supernatural being. This means that, for them, Jesus Christ was not the mediator between God and men.

According to Triebel (2002:190), the veneration of ancestors means that they are accorded serious and total respect. The place where the dead are buried is feared and regarded as sacred. As the whole burial site is thus regarded as sacred, no one is allowed to cultivate the ground, and neither is cattle allowed to graze there. One is not even allowed to cut down the bushes that grow in that area. A great deal of this respect or honour emanates from the African belief that their ancestors, as spirit beings, are in close contact with the supernatural being ${ }^{4}$ and this in itself demands good behaviour from them. According to Setiloane (1976:65), ancestors would reward those who treated them with respect and obedience with good health and prosperity, but they would punish those who neglected or offended them with sickness, economic loss or some mishap. The ancestors determine the lives of the living.

4 Modimo/God. 
In agreement with Triebel (2002) and Setiloane (1976), Kgosi Mankuroane (2017) sees nothing wrong with ancestor veneration and considers it part of the customs and traditions of his tribe. He emphasises the fact that, although ancestor veneration is part of the customs and traditions of his tribe, he and his tribal authority cannot force anyone to venerate ancestors and cannot stop them from doing so either. Personally, as well as in his capacity as a traditional leader, he holds a very strong belief that ancestors have a crucial place in society and its well-being, as in the days of his forefathers, despite the fact that he professes to be a Christian.

Kgosi Mankuroane goes on to state that rituals associated with ancestors merely serve to show appreciation and to seek guidance and protection. According to him, children's show of respect to, and communication with their parents, along with the guidance and protection their parents provided for them in childhood, do not cease upon the death of the parents. He respects the ancestors, but he does not personally venerate them; however, it remains a part of his tribe's culture that he as Kgosi must uphold. Mankuroane's (2017) view resonates with Nürnberger's (2007:19) and Mbiti's (2008:75-85) reference to "the living dead" who still care for their children. For his part, Igba (2013:27) insists that, in terms of the African world view, the existence of God the creator as well as the existence of ancestors are not debatable, but rather regarded as a given.

Mankuroane (2017) very strongly opposes the use of sangomas in any traditional function. According to him, the concept of bosangoma is foreign to Batswana as a whole, as it resides with both the Xhosas and the Zulus. This assertion is completely in line with Dube (2014:159), who contends that

Batswana indigenous healer-doctors are often categorised into two: dingaka tsa dinaka and dingaka tse ditshotsha. The category of dingaka tse ditshotsha consisted of indigenous healers who had extensive knowledge of healing herbs for various ailments. However, they did not use any form of divinity ... the sangomas, initially prominent among the Nguni-Venda-Shona cultural groups, are spirit mediums who use dreams, visions, dance and trance to diagnose the health of an individual.

Again, Mankuroane argues from his understanding of the culture, and not from a Christian perspective. What influence Christianity has on this belief is not clear.

Mhlophe (2013:100) records that a sangoma is a person called by ancestors to be a diviner, which belongs to the category that includes 
witchdoctors and spiritual healers. In agreement with Mhlophe, Gratz (2016: iii) notes that many people use the terms "sangoma" and "witchdoctor" interchangeably, although the former is considered more compassionate and the latter more destructive.

Having examined the role of traditional leaders in protecting their culture and the conundrum that arises from that exercise, it will also, to a great extent, be helpful to understand the source or perceived source of the conflict between Batswana or African traditions and culture, on the one hand, and Christianity, on the other. The truth is that sometimes the flame of conflict is fanned by a perception that seeks to equate missionaries and Christianity with colonisation.

\section{COLONISERS - TRANSFORMATIVE CULTURE}

As discussed earlier, Kgosi Mankuroane defended culture by emphasising that it goes to the root of every nation, tribe or community. This is in line with Chike (2008:221), who observes that African leaders and intellectuals have challenged all Africans not to lose their cultural and philosophical heritage upon conversion to Christianity. The main problem that gave rise to this appeal was the fact that the early missionaries to Africa insisted that true converts should renounce everything that was African. Zwetsch (2015:534) contends that "one of the ways Christian missionaries traditionally found to integrate the indigenous peoples into the colonial system was the Christian catechesis ... to dominate, or colonize the minds, hearts and imaginations of the indigenous people". Sometimes, mission was simply teaching the indigenous people the culture of the colonial authority. There was a lack of understanding of the African culture, and the transformation of the culture was not developed in a such way that the gospel could support it (Verster 2017:202).

Chike (2008:238) continues to argue that, although Christianity was, at times, presented as though it was culture-neutral, it was, in fact, highly influenced by the western culture, causing many Africans to equate missionaries with colonisers. According to Zwetsch (2015:534), the consequence of the attitude of the missionaries or colonisers was to consider the traditional indigenous religious world view as idolatrous, barbaric, and subject to error.

In addressing this colossal error, what is perhaps of paramount importance is that the current bearers of the gospel need to critically be circumspect in packaging their message, in order to minimise the Western 
under- or overtones of the biblical message. They need to realise that there are good and biblically sound Batswana customs and practices, just as there are evil Western tendencies which, unfortunately, present themselves masked by the gospel message. It is a real danger that all cultures will be subsumed into the consumer cult, if Jesus Christ is not acknowledged as the King over all people and creation.

The issue of the proper packaging of the gospel remains crucial. Even Kraft (2006:389) observed that the apostles contextualised Christianity. He mentions that, while the Christian message was mostly in Aramaic language and culture, when the apostles sought to communicate it to the Greeks, they expressed it in the thought patterns of the receptors. What the apostles did was significant in the sense that a Christianity characterised and dominated by foreign cultural norms and standards is both anti-scriptural and syncretistic. Hesselgrave (2006:395) states it profoundly when he suggests that Bible interpreters need to guard against the inclination of presenting the Bible message within his/her own cultural background so that the crux of the message is not missed or perverted. The Holy Spirit, also sent by Christ, brings the total renewal and healing of the community to the glory of God (Verster 2017:198).

However, and almost in response to the above, Van der Walt (2008:480) cautions as follows:

Traditionalism or conservatism is the attitude or tendency of adhering rigidly to the past old ideas or practices and to resist change. It implies closed, with no appreciation for the good to be found in the new and the present. Our standpoint must be that the past was not always necessarily correct because our elders and forefathers were not perfect beings and we have to explore new avenues and have courage do to away with ways which cannot stand the test of time. We should be open-minded enough to realise and to accept the good things or virtues of the present age. Neither the past nor the present is absolutely good or absolutely bad. Both should be judged by the infallible yardstick - that is the word of God.

From the foregoing, it is safe to suggest that, although Africans equated missionaries to colonisers because of mistakes the latter made due to their pre-conceived ideas about Africa, Van der Walt (2008) acknowledges the mistakes of the past and appeals for a transformative mindset. Equally, Danfulani (2012:61) is appealing to Africans to realise that, generally, cultures are constantly shifting in their patterns, values, and commitments. In other words, what Danfulani (2012) suggests is that culture is not static, but continuously changing or transforming. The truth is that, due to the fall in the Garden of Eden, all of men's culture became tainted with sin. We also 
need to note the fact that God can work in every culture. Kraft (2006:391) argues that

God's working within culture never leaves that culture unchanged. God changes people first, then through them the cultural structures. Whatever changes are to take place in the structures are to be made by the people themselves on the basis of their understanding scriptures and God's workings in their lives.

In essence, this means that the church, as the body of Christ and as a vehicle that God uses to touch and transform lives, has to be a direct agent of the Holy Spirit in changing traditional norms and culture, especially those that do not conform to the Word of God. In Matthew 13:33, Jesus Christ states that

[t]he Kingdom of heaven is like yeast that a woman took and mixed into a large amount of flour until it worked all through the dough.

To a large extent, this speaks of conversion that involves a break with the past. Kietzman and Smalley (2006:480), however, caution that

culture change comes only as an expression of a need felt by individuals within a society. People do not change their behaviour unless they feel the need to do so.

Christians (at least those from the reformed theology) know that God always creates an escape route, a way out of any difficult situation: "Behold, I will do a new thing ..." (Isa. 43:19). He echoes the same sentiments through the mouth of Apostle Paul in 1 Corinthians 10:13: “... he will also provide a way out". Irrespective of how big the conundrum is, there can be a way out of it.

\section{WAY OUT OF THE CONUNDRUM}

According to Dia (1994:176), effective leadership is about making a powerful connection between objects, human beings, and the supernatural. The guiding principle should be a desire to reach equilibrium with other human beings and the supernatural. Self-reliance, self-service and selfinterest should be given up in favour of the group or community loyalty.

The interest of the other is very profound, because it is very clear that right from the onset, from the time of creation as recorded in the creation account, ${ }^{5}$ God's wish was to be in contact and fellowship with man. It is

5 Book of Genesis. 
also clear that the primary purpose of God creating man in His image was, as Waltke (2007:254) puts it, for man to be God's proxy to rule over all things on earth.

Kerr (1989:21) and Mogapi (1991:137) opine that God has imparted to all men a certain understanding and comprehension of his divinity. In agreement with both Kerr and Mogapi, Horst (2013:93) adds that every man has a sensus divinitatis, which he describes as a mental faculty with the primary function of producing an idea of, or about God. Wright (2006:422) prefers to call it a God-awareness, or God-openness, that is common to all humanity.

A lesson can be learned from Kgosi Mangope (Shaffer 1963:6-7). Sometimes, as a leader, one is called upon to make difficult choices. His rejection of circumcision school and everything that comes with it, while simultaneously upholding certain traditions and customs as a traditional leader, speak of the need for leaders to be bicultural:

[T]o be bicultural means to be able to successfully manage the beliefs, values, standards and expectations of both the dominant culture and one's culture even though one's culture is devalued by the dominant culture (Parker 1996:204).

Based on Mangope's lesson, when one culture is in conflict with Christianity, the dominant culture ought to be Christianity. I referred earlier to conversion: to carry the title of a Christian means that the individual, be it a Kgosi or a commoner, has converted to Christianity. It is crucial to allow the Holy Spirit to effect change within us and/or transform even the way in which we perceive things. Then and only then can we respond positively to the advice of Apostle Paul (Rom. 12:2) "... do not be conformed to this world, but be transformed by the renewing of your mind ...". Conversion not only means breaking with the past, but also entails casting off the old self. Apostle Paul profoundly states in 2 Corinthians 5:17:

Therefore, if anyone is in Christ, he is a new creation, old things have passed away, behold all things have become new.

In other words, true and serious conversion to Christ is bound to thoroughly transform any tradition, culture and customs.

What remains of paramount importance, in this instance, is to isolate proper Christian doctrines and to identify and set parameters that would prevent harmless indigenous traditions and customs from being discarded completely when embracing the gospel: 


\begin{abstract}
Christ remains above culture because $\mathrm{He}$ fulfils, completes and perfects every human culture ... It was this transforming culture of Jesus Christ that came to Africa and swept aside the culture of ignorance and darkness that held millions in bondage. Christ is still transforming lives and communities in Africa today (Danfulani 2012: 67).
\end{abstract}

Although some Batswana adhere to the cultural practice of ancestor veneration, Bae (2007:161) and Wright (2006:171) point to the inevitable conclusion that any respect, dependency, appreciation or veneration (due to God) shown to an entity, ideology or person other than God constitutes a form of idolatry. Bae (2007:163) takes it even further by suggesting that attributing divine characteristics and seeking divine favour from a person (alive or dead) is in itself idolatry, which is in direct opposition to the Word of God.

\title{
6. SUMMARY
}

It is important and basic that traditional leaders are human beings and face different challenges in their day-to-day lives. What compounds their challenges is the responsibility entrusted upon them as custodians of traditions, customs and culture.

It is equally important that the moment a traditional leader accepts and/or embraces Christianity, he must accept and embrace the Holy Spirit to work in, and through him. He should be quick to also embrace what Parker (1996) earlier referred to as biculture, with the full understanding and willingness that, whenever his culture is in conflict with the Word of God, the latter will and should take precedence. In other words, when faced with the conundrum of choosing between traditions and the Word of God, traditional leaders should choose the latter. Wright (2006:188) states more plainly that the mission of God is to restore creation to its former glory and original purpose. God, therefore, battles against all forms of idolatry and calls us to join him in that conflict. Erickson (2013:343) emphasises that the biblical lessons on creation completely disallow any notion of dualism.

In other words, where God is in conflict with traditions in worship or reverence, he should be the natural choice. Nyirongo (1997:43) defines true worship as bequeathing or granting our hearts to Christ, our Redeemer, and serving him authentically in every area of our lives. In other words, humanity has to live in total obedience to God.

Given the fact that every believer is entrusted with the great commission (Matt. 28:19-20) of making disciples, a traditional leader, by virtue of him being a leader, should not abdicate that responsibility nor should he endeavour to separate himself from his people. He should rather seek to 
help them (like a small amount of yeast mixed with dough - Matt. 13:33) to be obedient to God. This is crucial in that a disciple of Jesus Christ ought to be willing to reform his own understanding of the gospel in order to be more like Christ (i.e. full of empathy for the broken world and having a deepseated desire for the transformation of his community under the guidance of the Holy Spirit). Secondly, he must endeavour to never separate his personal beliefs from his responsibility as custodian of the culture and traditions of his subjects. Instead, he should lead his people in finding their community values and identity in Christ and transform their culture from within, in order to give account of Christ's atonement and victory.

This also calls upon the church to embrace traditional leaders with total compassion in the knowledge that their own understanding of the implication of Christ as King over all people and creation can be flawed. The church, as the body of Christ, must strive to always exhibit the compassion of Jesus Christ by getting involved in the affairs of the community in such a manner that it can potentially change the perspective of the traditional leaders and the community in relation to the church itself, but more importantly in relation to the Gospel. Goheen (2011:212) notes that, through this involvement, society or the community will cease to view the church as alien or a group of people meeting for their own selfish purposes, but rather as a welcome presence in their midst, bringing blessings to them.

Danfulani (2012:67) emphasises that diabolical African practices and cultures should not be allowed, but rather be uprooted in an endeavour to allow Christianity to develop deep taproots into the rich spiritual soil of Motswana (the African).

All must humbly partake in the missio Dei and help each other transform culture to the glory of God. It is important to form a Christian world view that includes all aspects of life. Christ alone can accomplish this, because he is one with God and salvation is in him alone. Christians must find their new identity in Jesus Christ and their transformed culture must uphold their traditions and customs that are in line with the gospel, so that they may live in love together and in an orderly society.

\section{BIBLIOGRAPHY}

AMANZE, J.N.

2000. African Christianity in Botswana: The case of African independent churches. Gweru: Mambo Press.

2003. Christianity and ancestor veneration in Botswana. Studies in World Christianity 9(1):43-59. https://doi.org/10.3366/swc.2003.9.1.43 
Anagwo, E.C.

2014. Christianity and the African culture: Integrating the vision of liturgical inculturation. African Ecclesiastical Review 56(4):276-299. ATLA Religion Database.

BAE, C.S.

2007. Ancestor worship and the challenges it poses to the Christian mission and ministry. Unpublished Ph.D. thesis. Pretoria: University of Pretoria.

Cant, M.C., Brink, A. \& BriJball, S.

2006. Consumer behaviour. Cape Town: Juta.

CHIKE, C.

2008. Proudly African, proudly Christian: The roots of Christologies in the African worldview. London: Equinox Publishing. https://doi.org/10.1558/blth2008v6i2.221

Danfulani, U.H.D.

2012. African culture, Christ and the academia: The need to Christianise the African cultural matrix. Ogbomoso Journal of Theology 17(1):39-73.

DIA, M.

1994. Indigenous management practices: Lessons for Africa's management in the 1990s. In: I. Serageldin \& J. Taboroff (eds), Culture and development in Africa (Washington, DC: World Bank), pp. 165-191.

DuBE, M.W.

2014. Translating Ngaka: Robert Moffatt rewriting an indigenous healer. Studia Historiae Ecclesiasticae 40(1):157-172.

ERICKSON, M.J.

2013. Christian theology. $3^{\text {rd }}$ edition. Grand Rapids, MI: Baker Academic.

GoheEn, M.W.

2011. A light to the nations. The missional church and the biblical story. Grand Rapids, MI: Baker Academic.

Gratz, W.A.

2016. Influence of ancestral worship on participation in the missio Dei in King William's Town in the Eastern Cape. Unpublished MA dissertation. Mafikeng: University of the North West.

Hesselgrave, D.J.

2006. The role of culture in communication. In: R.D. Winter \& S.C. Hawthorne (eds), Perspectives on the World Christian Movement: A reader (Pasadena, CA: William Carey Library), pp. 392-396.

Hiebert, P.G.

2006. Cultural differences and the communication of the gospel. In: R.D. Winter \& S.C. Hawthorne (eds), Perspectives on the World Christian Movement: A reader (Pasadena, CA: William Carey Library), pp. 373-383. 
HORST, S.

2013. Notions of intuition in the cognitive science of religion. Monist 96(3): 377398. https://doi.org/10.5840/monist201396317

IGBA, J.T.

2013. Ancestor Christology and Jesus' identity: A study based on Epistle to the Hebrews. Unpublished MA dissertation. Potchefstroom: University of the North West.

Jebadu, A.

2007. Ancestral veneration and the possibility of its incorporation into the Christian faith. Exchange 36(3):246-280. https://doi.org/10.1163/157254307X205757

KERR, H.T.

1989. Calvin's Institutes: A new compendium. Louisville, KY: Westminister/John Knox Press.

Kietzman, D.W. \& Smalley, W.A.

2006. The missionary's role in culture change. In: R.D. Winter \& S.C. Hawthorne (eds), Perspectives on the World Christian Movement: A reader (Pasadena, CA: William Carey Library), pp. 480-482.

KRAFT, C.H.

2006. Culture, worldview and contextualization. In: R.D. Winter \& S.C. Hawthorne (eds), Perspectives on the World Christian Movement: A reader (Pasadena, CA: William Carey Library), pp. 384-391.

MankuRoane, L.

2017. History of Batlhaping ba-ga Phuduhucwana. Personal interview, 17 February, Taung.

MBITI, J.S.

1977. Christianity and African culture. London: Heinemann.

2008. The African religions and philosophy. $2^{\text {nd }}$ edition. Sandton: Heinemann.

Mhlophe, A.

2013. Christianity and the veneration of ancestors: Should a Christian consult the dead? Bellville: SALT Publishers.

MogaPI, K.

1991. Ngwao ya Setswana. Gaborone: L.Z. Sikwane Publishers.

NüRnBERgER, K.

2007. Christ and the ancestors in a changing Africa. The living dead and the living God. Pietermaritzburg: Cluster Publications.

NYIRONGO, L.

1997. The gods of Africa or the God of the Bible? The snares of African traditional religion in biblical perspective. The Potchefstroom University for Christian Higher Education: IRS. 


\section{PARKER, P.S.}

1996. Gender, culture and leadership: Toward a culturally distinct model of African-American women executives' leadership strategies. The Leadership Quarterly 7(2):189-214. https://doi.org/10.1016/S1048-9843(96)90040-5

RAY, C.B.

1976. African religions, symbols, rituals and community. Englewood Cliffs, NJ: Prentice-Hall.

SAMATAR, A.I.

1997. Leadership and ethnicity in the making of African models: Botswana versus Somalia. Third World Quarterly 18(4):687-707. https://doi. org/10.1080/01436599714713

Setiloane, G.M.

1976. The image of God among the Sotho-Tswana. Rotterdam: A.A. Balkema.

SHAFFER, E.E.

1963. Chief Lucas attains his goal. Pentecostal Evangel, 24 February:6-7.

The Holy Bible

1982. New King James Version.

TRIEBEL, J.

2002. Living together with the ancestors: Ancestor veneration in Africa as a challenge for missiology. Missiology. An International Review 30(2):187-197. https://doi.org/10.1177/009182960203000205

VAN DER WALt, B.J.

2001. Transformed by the renewing of your mind: Shaping a biblical worldview and a Christian perspective on scholarship. Potchefstroom: Institute for Contemporary Christianity in Africa.

2008. Man and God: The transforming power of biblical religion. Potchefstroom: Institute for Contemporary Christianity in Africa.

Verster, P.

2017. Jesus Christus, Seun van God, is ons Versoening - 'n Missionêre Christologie. Bloemfontein: Sun Press. https://doi.org/10.18820/9781928424116

Volz, S.

2008. Written on our hearts: Tswana Christians and the "word of God" in the mid-nineteenth century. Journal of Religion in Africa 38:112-140. https://doi. org/10.1163/157006608X289657

WALTERS, M.L.

2010. The influence of culture on customers' complaint behaviour pertaining to service failures. Unpublished MA dissertation. Potchefstroom: North-West University. 
WALTKE, B.K.

2007. An Old Testament theology: An exegetical, canonical and thematic approach. Grand Rapids, MI: Zondervan.

WRIGHT, C.J.H.

2006. The Mission of God. Unlocking the Bible's grand narrative. Downers Grove, ILL: IVP Academic.

ZWETSCH, R.E.

2015. Intercultural theology and the challenge of the indigenous peoples in Latin America. Southern African Journal of Missiology 43(3):526-544. https:// doi.org/10.7832/43-3-134

Keywords

Culture

Ancestors

Colonising

Worldview
Trefwoorde

Kultuur

Voorvaders

Kolonisering

Wêreldbeeld 